\title{
PENERAPAN MODEL ARGUMEN DRIVEN INQUIRY DALAM PEMBELAJARAN FISIKA TERHADAP KETERAMPILAN PROSES SAINS PESERTA DIDIK KELAS $X$ MIA SMA NEGERI 7 BONE
}

\author{
*Isna Pujianti \\ Universitas Negeri Makassar \\ isnapujiantisamad@gmail.com \\ Herman \\ Universitas Negeri Makassar \\ herman@unm.ac.id \\ Kaharuddin \\ Universitas Negeri Makassar \\ kaharuddin@unm.ac.id
}

\begin{abstract}
Abstrak - Penerapan Model Argument Driven Inquiry dalam Pembelajaran Fisika terhadap Keterampilan Proses Sains Peserta Didik Kelas X MIA 1 SMA Negeri 7 Bone. Penelitian ini merupakan penelitian pra eksperimen yang bertujuan untuk meningkatkan keterampilan proses sains fisika peserta didik. Model argument driven inquiry sebagai variabel bebas dan variabel terikat adalah keterampilan proses sains peserta didik dalam pembelajaran fisika. Subyek penelitian adalah peserta didik kelas X MIA 1 SMA Negeri 7 Bone. Data dianalisis dengan analisis deskriptif kuantitatif dan uji $\mathrm{N}-$ Gain. Berdasarkan analisis statistik, skor rata-rata untuk pretest 35 siswa adalah 3,6 dan skor rata-rata untuk post test 35 siswa adalah 8,3 . Kemudian hasil analisis dengan uji N-Gain diperoleh peningkatan keterampilan proses sains dalam pembelajaran fisika peserta didik dengan indikator mengklasifikasi, menafsirkan, menerapkan konsep, dan mengomunikasikan sebesar 0,8 dalam kategori tinggi. Maka disimpulkan bahwa model pembelajaran argument driven inquiry dapat meningkatkan keterampilan proses sains peserta didik
\end{abstract}

Kata Kunci : Model argument driven inquiry, keterampilan proses sains.

Abstract - The application of Argument Driven Inquiry Model in learning physics towards Students Science Processing Skill of the Tenth Grade Students of Senior High School 7 Bone.This research is a pre-experimental study which aims to improve the science process skills of students in physics learning. The argument driven inquiry model as an independent variable and the dependent variable is the science process skills of students in physics learning. The research subjects in this study were students of class X MIA 1 at SMA 7 Bone. Data were analyzed by quantitative descriptive analysis and $N$-Gain test. Based on statistical analysis, the average score for the pretest of 35 students was 3.6 and the average score for the post-test of 35 students was 8.3 Then the results of the analysis with the $N$-Gain test obtained an increase in science process skills in physics learning of students with indicators of classifying, interpreting, applying concepts, and communicating by 0.8 in the high category. It can be concluded that the argument driven inqiry learning model can improve the science process skills.

Keywords: Argument driven inquiry model, science processing skill. 


\section{A. PENDAHULUAN}

Keberhasilan pembelajaran sangat ditentukan apabila pembelajaran tersebut mampu mengembangkan potensi-potensi yang dimiliki peserta didik sehingga peserta didik dapat memperoleh manfaatnya secara langsung dalam perkembangan pribadinya. Namun, tak menutup kemungkinan pembelajaran fisika juga memiliki banyak permasalahan pada pelaksanaannya. Permasalahan pada pembelajaran konvensional dapat diatasi dengan penerapan pembelajaran inovatif. Pembelajaran inovatif merupakan pembelajaran yang mampu menarik perhatian peserta didik melalui pelibatan aktif peserta didik yang bersangkutan.

Berkaitan dengan hal tersebut, perlu dirancang suatu kegiatan belajar yang menarik bagi peserta didik. Pembelajaran inovatif diharapkan mampu meningkatkan keterampilan peserta didik.Peserta didik mudah memahami konsep-konsep yang rumit dan abstrak jika disertai dengan contoh-contoh konkrit merupakan salah satu alasan yang melandasi perlunya diterapkan keterampilan proses sains (Moedjiono, 2002).

Pembelajaran fisika yang dilakukan selama ini di sekolah tersebut tidak melibatkan keterampilan proses sains peserta didik. Peserta didik kurang diarahkan untuk fokus pada keterampilan prosesnya. Hasil observasi juga menunjukkan pembelajaran fisika yang dilakukan cenderung menekankan pada hasil evaluasi karena masih banyak peserta didik yang beranggapan bahwa capaian nilai tinggi adalah hal yang paling utama. Hal tersebut menunjukkan bahwa banyak peserta didik yang belum mengaplikasikan konsep-konsep yang telah dipelajari di sekolah dalam kehidupan sehari-hari. Keadaan tersebut tentu tidak begitu efektif dalam pembelajaran fisika jika hanya berpatokan pada hasil belajar tanpa memperhatikan prosesnya.

Keterampilan proses sains sebagai pendekatan dalam pembelajaran sangat penting karena menumbuhkan pengalaman selain proses belajar. Sehingga, perlu upaya meningkatkan efektivitas pembelajaran, khususnya prestasi hasil belajar kognitif yang didukung oleh keterampilan serta sikap dan prilaku yang baik. Oleh karena itu, para guru hendaknya secara bertahap mulai bergerak melakukan penilaian hasil belajar dalam aspek keterampilan dan sikap.

Perlu adanya peran guru dalam menentukan model pembelajaran yang tepat, dimana tidak hanya berpengaruh terhadap hasil belajar saja, tetapi dapat juga berpengaruh terhadap keterampilan prosesnya. Keterampilan proses dalam bidang ilmu pengetahuan alam adalah pengetahuan tentang konsep-konsep dalam prinsip-prinsip yang dapat diperoleh peserta didik bila dia memiliki kemampuan-kemampuan dasar tertentu yaitu keterampilan proses sains yang dibutuhkan untuk menggunakan sains.

Salah satu solusi yang dipandang dapat meningkatkan keterampilan proses sains peserta didik adalah dengan menerapkan model pembelajaran inkuiri dimana pembelajaran inkuiri menuntut peserta didik untuk ikut terlibat aktif dalam kegiatan penyampaian argumentasi ilmiah, karena keterampilan argumentasi ilmiah merupakan aspek penting dalam keterampilan proses sains. 
Argumentasi merupakan bagian yang tidak dapat dipisahkan dari sains. Dalam praktek pembelajaran sains, argumentasi merupakan hal utama yang melandasi siswa dalam belajar bagaimana berpikir, bertindak dan berkomunikasi seperti seorang ilmuwan. Kemampuan argumentasi menjadi salah satu sarana untuk memenuhi tujuan utama pembelajaran sains. Karena siswa yang belajar sains harus mengetahui penjelasan interaksi manusia dengan alam. Pembelajaran fisika melalui model Argument Driven Inquiry (ADI) diperlukan untuk mengembangkan keterampilan proses sains peserta didik.

Model pembelajaran ADI dirancang untuk memagari tujuan inkuiri ilmiah sebagai upaya untuk meningkatkan keterampilan proses sains yang menyediakan dan mendukung rumusan masalah. Sebagai bagian dari upaya ini, peserta didik diarahkan untuk merancang dan melaksanakaan penyelidikan sendiri, mengumpulkan dan menganalisis data, berkomunikasi dan membenarkan ideide satu sama lain dengan selama sesi argumentasi interaktif, menulis laporan investigasi untuk berbagi dan mendokumentasikan pekerjaan, dan terlibat dalam peer-review. Proses seperti ini memberikan peserta didik kesempatan untuk mengambil kepemilikan belajar menjadikan proses belajar menjadi miliknya dan membantu peserta didik membuat pekerjaan laboratorium menjadi lebih mendidik bagi peserta didik (Hasnunidah, 2015).

\section{B. METODE}

Penelitian ini merupakan penelitian pra eksperimen. Subjek dalam penelitian ini adalah peserta didik kelas X MIA 1 SMA Negeri 7 Bone yang berjumlah 35 orang.

Variabel dalam penelitian ini adalah Model ADI dan keterampilan proses sains peserta didik dalam pembelajaran fisika. Indikator keterampilan proses sains yang digunakan adalah menafsirkan, menerapkan konsep, dan melakukan komunikasi.

Teknik pengumpulan data digunakan dalam penelitian ini adalah dengan pemberian instrumen tes keterampilan proses sains peserta didik berupa pretest dan posttest dengan materi gerak harmonik sederhana.

Penelitian menggunakan analisis deskriptif dan analisis N-Gain. Teknik analisis ini bermaksud untuk mendeskripsikan atau menggambarkan data yang telah terkumpul. Untuk data yang diperoleh yaitu pada hasil tes serta data hasil dokumentasi akan ditentukan besarnya persentase dari tiap indikator keterampilan proses sains beserta berapa peningkatannya melalu uji $\mathrm{N}$-gain.

\section{HASIL DAN PEMBAHASAN}

Skor Pretest Keterampilan proses sains peserta didik kelas X MIA 1 yang berjumlah 35 orang diperoleh (x $\overline{)}$, varians (S2), dan standar deviasi (S) seperti yang terlihat pada Tabel 1. Nampak pada tabel 1 diperoleh skor rata-rata yang dimiliki peserta didik sebesar 3,6 dimana berada pada kategori sedang. berdasarkan distiribusi frekuensi pengkategorian skor keterampilan proses sains peserta didik diperoleh persentase tertinggi sebesar $60 \%$ dengan frekuensi 21 dimana termasuk dalam kategori 
sedang. hasil pretest keterampilan proses sains peserta didik tiap indikator. Berdasarkan hasil pretest yang dilakukan maka dikategorikan persentase soal untuk setiap indikatornya seperti tabel 1 berikut

Tabel 1. Hasil Pretest Keterampilan Proses

\begin{tabular}{cc}
\hline Kategori & Skor \\
\hline Skor terendah & 2,0 \\
Skor tertinggi & 7,0 \\
Skor ideal & 11,0 \\
Skor rata-rata & 3,6 \\
Standar deviasi & 1,2 \\
Varians & 1,4 \\
\hline
\end{tabular}

\begin{tabular}{clcc}
\hline No & \multicolumn{1}{c}{ Aspek } & Persentase (\%) & Kategori \\
\hline $\mathbf{1}$ & Menerapkan konsep & 32,9 & Rendah \\
$\mathbf{2}$ & Mengomunikasikan & 32,4 & Rendah \\
$\mathbf{3}$ & Menafsirkan & 33,6 & Rendah \\
\hline
\end{tabular}

Nampak pada tabel diperoleh bahwa aspek keterampilan proses sains yang memiliki persentase tertinggi pada saat diberikan pretest yaitu menafsirkan dengan persentase 33,6\% namun dengan kategori rendah dan aspek yang memiliki persentase terendah yaitu mengkomunikasikan 32,4\% dengan kategori rendah.

Skor Posttest Keterampilan proses sains peserta didik kelas X MIA 1 yang berjumlah 35 orang diperoleh $(\mathrm{x} \overline{)}$, varians (S2), dan standar deviasi (S) seperti yang terlihat pada table 2 sebagai berikut.

Tabel 2. Hasil Posttest Keterampilan Proses Sains

\begin{tabular}{cc}
\hline Kategori & Nilai \\
\hline Skor terendah & 5,0 \\
Skor tertinggi & 11,0 \\
Skor Ideal & 11,0 \\
Skor rata-rata & 8,3 \\
Standar deviasi & 1,3 \\
Varian & 1,7 \\
\hline
\end{tabular}

Berdasarkan tabel 2 diperoleh bahwa setelah diberikan posttest, skor peserta didik kelas X MIA 1 memiliki skor tertinggi 11,0 dan skor terendah 5,0 dengan skor ideal sebesar 11,0. Adapun skor ratarata (mean) dari hasil posttest diperoleh 8,3 . Untuk pengkategorian skor hasil posttest keterampilan proses sains peserta didik dapat dilihat pada table 3 berikut. 
Berdasarkan tabel tersebut diperoleh rata-rata nilai posttest peserta didik adalah 8,3 dimana masuk dalam kategori tinggi. Begitupula diperoleh pada tabel 4.5 persentase terbesar diperoleh dengan kategori tinggi dengan persentase $57,1 \%$. Sesuai hasil post test yang diperoleh maka dikategorikan persentase soal untuk setiap indikatornya seperti Tabel 3 berikut.

Tabel 3. Penngakategorian skor hasil posttest

\begin{tabular}{clcc}
\hline No & \multicolumn{1}{c}{ Aspek } & $\begin{array}{c}\text { Persentase } \\
\mathbf{( \% )}\end{array}$ & Kategori \\
\hline $\mathbf{1}$ & Menerapkan konsep & 71,4 & Tinggi \\
$\mathbf{2}$ & Mengomunikasikan & 80,0 & Tinggi \\
$\mathbf{3}$ & Menafsirkan & 75,0 & Tinggi \\
\hline
\end{tabular}

Nampak pada tabel diperoleh bahwa aspek keterampilan proses sains yang memiliki persentase tertinggi pada saat diberikan posttest yaitu mengkomunikasikan dengan persentase $80,0 \%$ dengan kategori tinggi .

Hasil analisis statistik deskriptif keterampilan proses sains peserta didik pada indikator menerapkan konsep juga diperoleh peningkatan skor. Skor peserta didik yang pada saat diberikan pretest tergolong rendah, dikarenakan peserta didik masih terlalu buram dan belum akrab dengan materi getaran harmonik sederhana. Pada tahap pemberian topik utama, dimana materi gerak harmonik sederhana mulai diperkenalkan, menuntut peserta didik untuk mencari dan menggali informasi sendiri berdasarkan topik yang diberikan. Peserta didik juga aktif mencari informasi pada tahapan pengumpulan data, proses praktikum yang dilaksanakan untuk mengumpulkan data membuat peserta didik lebih aktif dalam menerapkan konsep getaran harmonik yang telah didiskusikan sebelumnya. Sehingga, materi getaran harmonik sederhana lebih real dalam penerapan konsepnya pada proses praktikum. Peneliti juga memberikan instrument keterampilan proses sains untuk indikator menerapkan konsep yang berkenaan dengan hasil pembelajaran. Penelitian ini juga pernah dilakukan oleh (Andriani, 2015) yang didapatkan bahwa model pembelajaran Argument Driven Inquiry dapat meningkatkan penguasaan konsep peserta didik.

Model ADI dalam pembelajaran yang diterapkan dapat melatih peserta didik berargumen. Setelah diperoleh argumentasi kelompok di fase diskusi reflektif ekspisit, peserta didik mengemukakan pendapat tiap kelompok pada fase argumentasi sesuai dengan yang telah mereka laksanakan di kelompok masing-masing. Kemudian, kelompok lain akan menyampaikan pendapatnya. Sehingga, peserta didik pada fase ini akan lebih aktif pada proses pembelajaran. Ini sesuai dengan penelitian yang telah dilakukan sebelumnya (Wahyu, 2015) yang mengatakan bahwa model ADI dapat meningkatkan kemampuan argumentasi peserta didik.

Rata-rata N-gain keterampilan proses sains pada materi getaran harmonik sederhana kelas X MIA 1 SMA Negeri 7 Bone sebesar 0,8. Besar peningkatan skor keterampilan proses sains peserta didik dapat diketahui dengan menggunakan uji N-gain. Nilai Gain digunakan untuk melihat seberapa 
besar peningkatan skor keterampilan proses sains peserta didik sebelum dan sesudah diajar dengan menggunakan model pembelajaran ADI.

\section{.D. SIMPULAN}

1 Skor keterampilan proses sains fisika peserta didik kelas X MIA 1 SMA Negeri 7 Bone sebelum diajar menggunakan model pembelajaran Argument Driven Inquiry sebesar 3,6 dengan kategori rendah.

2 Skor keterampilan proses sains fisika peserta didik kelas X MIA 1 SMA Negeri 7 Bone setelah diajar menggunakan model pembelajaran Argument Driven Inquiry sebesar 8,3 dengan kategori tinggi.

3 Peningkatan keterampilan proses sains fisika peserta didik kelas X MIA 1 SMA Negeri 7 Bone setelah diajar menggunakan model pembelajaran ADI sebesar 0,8 dengan kategori tinggi. Peningkatan ini tentu dipengaruhi oleh fase dalam mode ADI yang mengarahkan peserta didik untuk merancang dan melakukan penyelidikannya sendiri sehingga peserta didik lebih aktif dan terlibat langsung pada proses belajar.

\section{DAFTAR RUJUKAN}

Hasnunidah, N. (2015). Pembelajaran biologi dengan strategi argumen driven inquiry dan keterampilan argumentasi peserta didi. Jurnal Pendidikan Biologi FKIP, 8-9.

Indrawati. (1999). Keterampilan Proses Sains: Tinjauan Kritis dari Teori ke praktis. Bandung: Dirjen Pendidikan dasar dan menengah.

Kadayifcia H, A. B. (2012). The correlation between the flaws students define in argument and their creative and critical thinking abilities. Procedia social and behaviour science gazi university faculty of education, 802.

Meltzer, D. (2002). The Relationship between mathematics preparation and conceptual learning gains in physics. posisible "hidden variable" in diagnostic pretest scores. American journal of physics, 70 .

Moedjiono, D. (2002). Belajar dan Pembelajaran. Jakarta: PT.Rineka.

Nurmayani J Said, A. P. (2017). Peranan Model Pembelajaran Inkuiri Terbimbing terhadap Keterampilan Proses Sains pada Peserta didik kelas X SMA Negeri 2 Polewali. Jurnal Sains dan Pendidikan Fisika, 255-262.

Riduwan, M. (2008). Skala Pengukuran Variabel-Variabel Penelitian. Bandung: Alfabeta.

Sampson. (2014). Argument driven inquiry in biology. United States of America: NSTA Press.

Semiawan, C. (1986). Pendekatan Keterampilan Proses Sains. Jakarta: PT.Gramedia.

Sugiyono. (2014). Metode Penelitian Pendidikan (Pendekatan Kuantitatif, Kualitatif, dan R\&D). Bandung: ALFABETA. 
Yuli Andriani, R. (2014). Peningkatan Penguasaan Konsep Siswa Melalui Pembelajaran Argumen Driven Inquiry Pada Pembelajaran IPA Terpadu di SMP kelas VII. Jurnal Edusains UIN Jakarta Syarif Hidayatullah, 1. 